\title{
DNA Barcoding Dalugha (Cyrtosperma Merkusii) di Kepulauan Talaud dan Minahasa Selatan Berdasarkan Gen $r b c L$
}

\section{(DNA barcoding of Dalugha (Cyrtosperma merkusii) in Talaud Islands and North Minahasa Based on rbcL Gene}

\author{
Marlin Taariwuan ${ }^{{ }^{*}}$, Jantje Ngangi ${ }^{2}$, Yermia Mokosuli ${ }^{2}$, Sukmarayu Gedoan ${ }^{2}$ \\ ${ }^{1}$ Mahasiswa S2 Biologi PPs Universitas Negeri Manado \\ ${ }^{2}$ Staf Pengajar Prodi Biologi PPs UNIMA \\ *Email: bernadettaariwuan@gmail.com
}

(Article History: Received June 28, 2021; Revised August 30, 2021; Accepted Sept 3, 2021)

\begin{abstract}
ABSTRAK
Dalugha (Cyrtospera merkusii (Hassk.)Schott) merupakan tanaman endemik Sulawesi Utara yang digunakan sebagai pangan alternatif (penganti beras). Penelitian ini bertujuan untuk membandingkan spesies daluga di Kepulauan Talaud dan Minahasa Selatan menggunakan DNA barcode gen rbcL (ribulose 1,5 bisphosphate carboxylase large). Perbandingan barcode DNA yang dilakukan pada empat sampel yang berbeda lokasi tersebut keduanya menghasilkan tingkat kesamaan $100 \%$ (identik). Dengan demikian, tidak ada variasi intra spesies yang ditemukan dari semua sampel yang ada. Selanjutnya, kemiripan sampel-sampel ini telusuri kemiripannya dengan kerabat terdekat yang tercatat di GenBank menggunakan BLAST (Basic Local Alignment Search Tool). Tanaman dalugha dalam penelitian ini memiliki kemiripan 99,82\% dengan tumbuhan Anaphyllopsis americana (AM905753.1), dan kemiripannya 99,63\% dengan Cyrtosperma macrotum (AM905750.1), Lasimorpha senegalensis (AM905755.1), Pycnospatha arietina (AM905751.1), dan Podolasia stipitata (AM905752.1). Belum ada rekor sekuens DNA gen rbcL dari spesies ini yang dibisa dibandingkan di GenBank.

Kata Kunci: Dalugha; DNA barcoding; gen rbcL
\end{abstract}

Dalugha (Cyrtospera merkusii (Hassk.) Schott) is an endemic plant in North Sulawesi that is used as alternative food (substitute for rice). This research aimed to compare the DNA barcode of dalugha in Talaud Islands and in South Minahasa using rbcL (ribulose 1,5 bisphosphate carboxylase large) gene. The DNA barcoding comparison of all four samples in both area resulted in 100\% similarity (identical). Therefore, there is no intraspecific variation found in all samples. Furthermore, the similarity of these samples were conducted with BLAST (Basic Local Alignment Search Tool) to compare with its closest relatives in GenBank. The closest relatives of this plant, based on similarity information, are 99.82\% with Anaphyllopsis americana (AM905753.1) and all $99.63 \%$ with Cyrtosperma macrotum (AM905750.1), Lasimorpha senegalensis (AM905755.1), Pycnospatha arietina (AM905751.1), and Podolasia stipitata (AM905752.1). There is no record yet of rbcL gene sequence of $C$. merkusii in GenBank for comparison.

Keywords: Dalugha; DNA barcoding; rbcL gene

\section{PENDAHULUAN}

Genus Cyrtosperma memiliki jumlah spesies paling sedikit yaitu 12 spesies yang tersebar di Papua, Semenanjung Malaya, Filipina, Kalimantan, Sumatera, Jawa dan Oseania. Hasil penelitian terbaru di Federated States of Micronesia mengatakan bahwa di daerah Micronesia dan sekitarnya terdapat 37 kultivar Crytosperma dan masing-masing kultivar memiliki karakter morfologi berbeda (Rao et al. 2014). Propinsi Sulawesi Utara memiliki beragam pangan lokal yang berasal dari umbi dan berpotensi sebagai sumber pangan alternative untuk mendukung ketahanan pangan, seperti, Dalugha (Cyrtosperma merkusii) dan Kolerea (Colocasia $s p$ ) yang berasal dari Kepulauan Sangihe dan Talaud, Umbi wongkai (Dioscorea sp) di Kabupaten Minahasa Tenggara dan umbi Longki 
(Xanthosoma sp) di kota Bitung (Taulu dan Layuk 2014). Dalugha adalah nama lokal yang diberikan oleh Masyarakat untuk tanaman talas rawa merupakan sumber makanan (penganti beras) (Agustina et al. 2016).

Identifikasi spesies berdasarkan morfologi memiliki beberapa kendala, yaitu pada beberapa takson hanya bisa dilakukan pada tumbuhan dewasa (berbunga), sehingga memerlukan waktu yang lama untuk pengambilan sampel dan pengamatan harus menunggu masa berbunga atau berbuah (Virgilio et al. 2012). Seiring dengan kemajuan pesat biologi molekuler (DNA barcode) Gen COI untuk identifikasi secara molekuler khususnya pada hewan, sedangkan ITS, matK dan rbcL untuk tumbuhan (Rahayu et al. 2019). The Consortium for the Barcode of Life (CBOL) merekomendasikan penggunaan dua gen plastida $r b c L$ dan matK sebagai barcode standar (Hollingsworth et al. 2009). Gen rbcL (ribulose 1,5 bisphosphat carboxylase large) dapat diamplifikasi dengan tingkat keberhasilan tinggi dari satu atau dua macam primer universal. Lebih lanjut dikemukakan jika dibandingkan dengan kandidat gen barcode yang lain, gen $r b c L$ memiliki tingkat keberhasilan bidirectional sequencing (proses sequencing dua arah dengan primer forward dan reverse) yang tinggi (Fazekas et al. 2008).

Berdasarkan observasi di lapangan, dalugha tumbuh subur di rawa-rawa di Kabupaten Minahasa Selatan Desa Rap-Rap. Informasi masyarakat setempat bahwa dalugha digunakan sebagai bahan makanan untuk mengatasi krisis pangan. Penelitian ini bertujuan untuk membandingkan spesies dalugha di Minahasa Selatan dengan di kepulauan Talaud menggunakan sekuens barcode DNA berdasarkan gen $r b c L$. Serta membandingkan sekuens dalugha dengan beberapa kerabat terdekatnya yang terdata di GenBank.

\section{METODE}

\section{Isolasi DNA Tumbuhan Dalugha}

Tumbuhan dalugha dengan kode sampel AM, RP, TN, TA (telah melalui proses diidentifikasi secara morfologi sebelumnya) masing-masing diambil daunnya kira-kira 50 mg, kemudian digerus dalam tabung Eppendorf. Sampel yang sudah disiapkan dalam tabung Eppendorf diisolasi menggunakan Genomic DNA Mini Kit Plant (Geneaid) sesuai dengan prosedur manual yang disediakan perusahaan.

\section{Amplifikasi dengan Polimerase Chain Reaction (PCR)}

Reaksi PCR dilakukan dalam volume total $40 \mu \mathrm{L}$. Komposisi reaksi PCR mengandung $20 \mu \mathrm{L}$ MyTaq HS Red Mix (Bioline), 1,5 $\mu \mathrm{L}$ untuk masing-masing primer, $3 \mu \mathrm{L}$ templat DNA sampel, dan 14 $\mu \mathrm{L}$ air (deionisasi, bebas nuklease). Primer yang digunakan berdasarkan Kress dan Erickson (2007) yaitu rbcl-aF (5' ATG TCA CCA CAA ACA GAC ACT AAA GC- 3') sebagai primer maju dan rbcL-aR (5' GTA AAA TCA AGT CCA CCR CG-3') sebagai primer mundur.

Tahapan proses amplifikasi PCR meliputi denaturasi DNA awal pada suhu $95^{\circ} \mathrm{C}$ selama 3 menit, (i) denaturasi pada suhu $95^{\circ} \mathrm{C}$ selama 30 detik, (ii) perlekatan primer pada suhu $50^{\circ} \mathrm{C}$ selama 30 detik, (iii) pemanjangan DNA pada suhu $72^{\circ} \mathrm{C}$ selama 30 detik. Tahapan i, ii, dan iii berlangsung sebanyak 35 kali dan tahap pemanjangan akhir pada $72^{\circ} \mathrm{C}$ selama 60 detik (Kolondam, 2015). Proses amplifikasi dilakukan mesin PCR T-Personal (Biometra). Proses sekuensing dilakukan penyedia jasa sekuensing First Base C.O. di Malaysia.

\section{ANALISIS DATA}

Pembacaan kromatogram dan penyuntingan DNA dilakukan menggunakan piranti lunak Geneious v5.6 (Kearse et al. 2012). Penjajaran untuk dua arah sekuensing dilakukan menggunakan algoritma MUSCLE (Edgar 2004). Sekuens barcode DNA sampel dibuat dalam format FASTA untuk analisis selanjutnya. Identifikasi 
barcode DNA menggunakan BLAST (Basic Local Search Tool) yang tersedia secara daring (https://blast.ncbi.nlm.nih.gov/) tanggal 27 Juni 2021 (Altschul et al. 1990).

\section{HASIL DAN PEMBAHASAN}

Isolasi DNA merupakan tahap pertama dari berbagai teknologi analisis DNA, bertujuan untuk memisahkan DNA dari bahan lain seperti protein, lemak dan karbohidrat. Hasil isolasi dan amplifikasi gen $r b c L$ daluga memperlihatkan pola pita yang jelas dan tunggal, ditunjukkan dengan elektroforesis yang divisualisasikan dengan UV-Transluminator (Gambar 1).

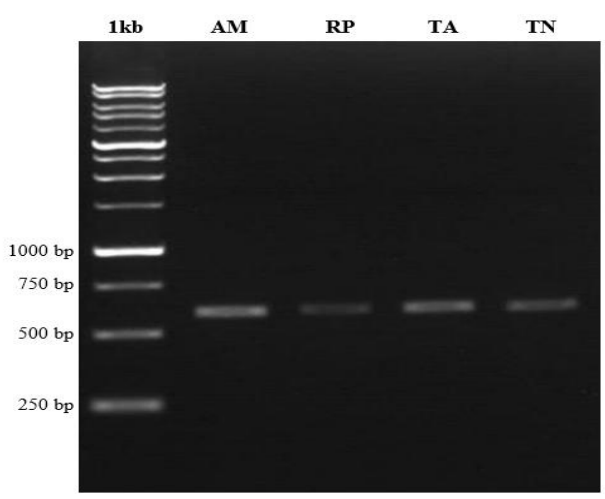

Gambar 1. Elektroforesis gel agarosa $0,8 \%$ produk PCR gen rbcL sampel

Pita DNA tunggal artinya DNA yang diperoleh tersebut utuh atau tidak ada smear ketika DNA dielektroforesis. DNA yang berkualitas baik dicirikan oleh pita DNA yang terlihat tebal dan bersih bila divisualisasikan foto gel elektroforesis (Ardiana 2009). Hal ini menjadi penting karena pada proses sekuensing DNA yang masih utuh akan memberikan hasil yang lebih akurat. Berdasarkan ukuran DNA ladder $1 \mathrm{~kb}$, pita DNA yang terbaca berukuran antara 500 bp dan 750 bp. Hasil ini sesuai dengan panjang pita yang diharapkan, yaitu $600 \mathrm{bp}$.

Hasil sekuensing produk PCR gen rbcL untuk semua sampel menghasilkan kromatogram yang berkualitas tinggi dengan nilai High Quality (HQ) lebih dari $90 \%$. Kromatogram hasil sekuensing menunjukkan hasil berkualitas tinggi, di mana puncak yang dihasilkan jelas dan tidak saling tumpang tindih antara satu puncak yang satu dengan yang lainya, semakin tinggi nilai HQ suatu kromatogram maka semakin bagus pula puncak kromatogram.

Hasil penjajaran (alignment) menunjukkan bahwa keempat sekuens tanaman daluga AM, RP, TA dan TN) semuanya identik (kesamaan 100\%). Hasil penjajaran sekuens gen rbcL menggunakan algoritma MUSCLE dapat dilihat pada Gambar 2. Ini berarti bahwa berdasarkan sekuens gen $r b c L$, perbedaan ciri morfologi dari tanaman daluga yang berbeda lokasi tidak berarti menunjukkan perbedaan spesies. Secara genetik keempatnya sama persis atau identik.

Hal ini disebabkan karena variasi genetik intraspesies sangat kecil. Selain itu, untuk mengetahui variasi intraspesies yang lebih akurat dibutuhkan dua atau lebih kombinasi lokus sehingga dapat menghasilkan data yang lebih signifikan (Newsmaster dan Ragupathy 2009; Tallei dan Kolondam 2015).

Hasil ini mirip dengan penelitian Julianti et al. (2015) yang sebelumnya membandingkan tanaman dalugha menggunakan DNA barcoding gen matK. Seperti layaknya gen matK, gen rbcL yang digunakan dalam penelitian ini tidak menunjukkan adanya variasi sama sekali antar sampel dari beberapa lokasi. Gen ini tidak menunjukkan adanya variasi intraspesies antar tanaman dalugha.

Hasil BLAST gen rbcL sampel keempat sampel dalugha yang identik tersebut menunjukkan tingkat kemiripan 99,82\% (Gambar 3) dengan tumbuhan Anaphyllopsis americana (AM905753.1), yang masih merupakan satu famili Araceae dengan tanaman Dalugha. Spesies yang paling mirip di urutan kedua ada empat spesies yang tingkat kemiripannya $99,63 \%$ yaitu Cyrtosperma macrotum (AM905750.1), Lasimorpha senegalensis (AM905755.1), Pycnospatha arietina (AM905751.1), dan Podolasia stipitata (AM905752.1). Lima spesies ini sama-sama termasuk family Araceae dan sub family Lasioideae. 


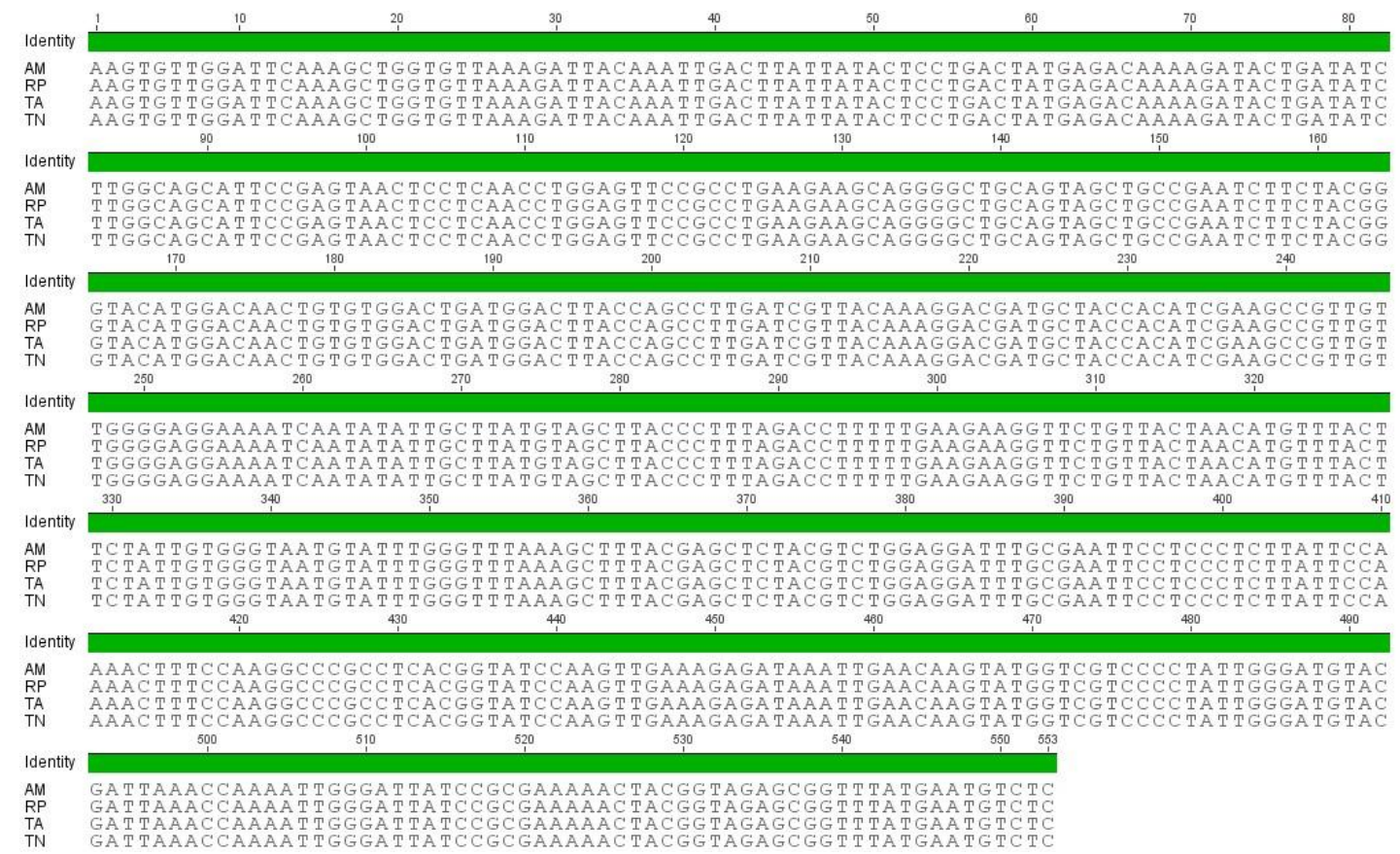

Gambar 2. Alignment (penjajaran) sekuens gen rbcL sampel daluga menggunakan algoritma MUSCLE.

\begin{tabular}{|c|c|c|c|c|c|c|c|c|c|}
\hline & $\mathrm{cri}$ & $\begin{array}{c}\text { Scientific } \\
\text { Name } \\
\vee\end{array}$ & $\begin{array}{l}\text { Max } \\
\text { Score } \\
\downarrow\end{array}$ & $\begin{array}{c}\text { Total } \\
\text { Score } \\
\nabla\end{array}$ & $\begin{array}{l}\text { Query } \\
\text { Cover } \\
\nabla\end{array}$ & $\underset{\forall}{E}$ & $\begin{array}{l}\text { Per. } \\
\text { Ident } \\
\checkmark\end{array}$ & $\begin{array}{l}\text { Acc. } \\
\text { Len } \\
\nabla\end{array}$ & Accession \\
\hline 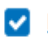 & a voucher 71753 (MO) chlo & asia spinosa & 1005 & 1005 & $100 \%$ & 0.0 & $99.46 \%$ & 169982 & $\underline{M}$ \\
\hline | & sia soinosa voucher $71753(\mathrm{MO}) \mathrm{Ct}$ & sa & 1005 & 1005 & $100 \%$ & 0.0 & $99.46 \%$ & 169982 & NC 048970. \\
\hline$\nabla$ & Lasia spinosa voucher PS1402MT03r & . Lasia spinosa & 1005 & 1005 & $100 \%$ & 0.0 & $99.46 \%$ & 703 & $\underline{\text { GQ436687.1 }}$ \\
\hline$\nabla$ & BioBot06550 ribulose-1 5 -bisphosphate carboxyl.. & Araceae $\mathrm{Sp}$ & 1003 & 1003 & $99 \%$ & 0.0 & $99.46 \%$ & 552 & $\underline{\mathrm{JQ} 590293.1}$ \\
\hline$\nabla$ & gene & $\underline{\text { Lasi }}$ & 1002 & 1002 & $99 \%$ & 0.0 & $99.46 \%$ & 1327 & $\underline{\mathrm{L} 10250.2}$ \\
\hline$\nabla$ & hate carb... & & 996 & 996 & 98 & 0.0 & $99.82 \%$ & 1391 & AM905753.1 \\
\hline$\nabla$ & te carb. & & 990 & 90 & 98 & 0.0 & $\%$ & 1391 & AM905755.1 \\
\hline$\nabla$ & ssphate carboxylase & sia st. & 99 & 90 & 9 & 0.0 & $99.63 \%$ & 1391 & 5752.1 \\
\hline$\nabla$ & hosphate carboxyl... & ;path. & 990 & 990 & $98 \%$ & 0.0 & & 1391 & 10 \\
\hline$\nabla$ & carbox. & erm... & 990 & 0 & $98 \%$ & 0.0 & & 1391 & 775 \\
\hline$\nabla$ & $\underline{A}$ & & 989 & 9 & & & & & 1 \\
\hline$\nabla$ & s & & 989 & 989 & & & & & 28.1 \\
\hline$\nabla$ & 促 & & 98 & 89 & $100 \%$ & 0.0 & $98.92 \%$ & 553 & 194.1 \\
\hline$\nabla$ & S:363223 & & 987 & 987 & $99 \%$ & 0.0 & $98.91 \%$ & 553 & $\underline{\text { MF786302.1 }}$ \\
\hline$\nabla$ & mutatum voucher Hosam00271 ribulose-1. & ma... & 987 & 987 & $99 \%$ & 0.0 & $98.91 \%$ & 552 & $\underline{\mathrm{KX} 783817.1}$ \\
\hline$\nabla$ & $\underline{\text { Caladiu }}$ & $m$ bi... & 987 & 987 & $99 \%$ & 0.0 & $98.91 \%$ & 163149 & MN972441.1 \\
\hline$\nabla$ & Xanthosoma sagittifolium chloroplast complete genome & $\underline{\text { Xanthosom... }}$ & 987 & 987 & $99 \%$ & 0.0 & $98.91 \%$ & 165169 & MW628970.1 \\
\hline$\nabla$ & sagittifolium voucher J.R. Abbott 24707 (FLAS) ribulose-1, 5-bispho.. & . Xanthosom... & 987 & 987 & $99 \%$ & 0.0 & $98.91 \%$ & 566 & $\underline{\text { GU135182.1 }}$ \\
\hline$\nabla$ & ulenta voucher BioBot05994 ribulose-1 1 -bisphosphate carboxylas. & Colo & 985 & 85 & $99 \%$ & 0.0 & $98.91 \%$ & 552 & $\underline{\text { JQ590298.1 }}$ \\
\hline 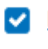 & Lasia spinosa plastid partial rbcL gene for ribulose-biphosphate carboxylase & Lasia spinosa & 985 & 85 & $98 \%$ & 0.0 & $5 \%$ & 1391 & AM905749.1 \\
\hline$\nabla$ & Xanthosoma mafaffa rbcL gene_partial & $\underline{\text { Xanthosom... }}$ & 905 & 85 & $99 \%$ & 0.0 & $98.91 \%$ & 1347 & A.J007543.1 \\
\hline$\nabla$ & Stylochaeton bogneri voucher 87579 (M & Stylochaeto.... & 3 & 83 & $100 \%$ & 0.0 & $\%$ & 3770 & 74.1 \\
\hline
\end{tabular}

Gambar 3. Hasil BLAST sampel

\section{KESIMPULAN}

DNA barcoding berdasarkan penanda gen $r b c L$ yang dilakukan pada empat sampel yang berbeda lokasi (Kepulauan Talaud dan
Minahasa Selatan) menghasilkan tingkat kesamaan $100 \%$ atau disebut identik. Tidak ada variasi intraspesies yang ditemukan dari sampel yang ada. Kerabat terdekat tanaman 
dalugha dalam penelitian ini memiliki kemiripan 99,82\% dengan tumbuhan Anaphyllopsis americana (AM905753.1), dan kemiripannya $99,63 \%$ dengan Cyrtosperma macrotum (AM905750.1), Lasimorpha senegalensis (AM905755.1), Pycnospatha arietina (AM905751.1), dan Podolasia stipitata (AM905752.1) yang termasuk famili Araceae dan sub famili Lasioideae.

\section{DAFTAR PUSTAKA}

Agustina DN, Faridah, Jenie BSL, (2016) Pengaruh Retrogradassi dan perlakuan kelembaban panas terhadap kadar pati resisten tipe 3. Daluga. Jurnal Teknologi dan Industri Pangan. 27:7886.DOI:10,6066/Jtip.2016.27.1.78.

Altschul, SF., Gish, W., Miller, W., Myers, E.W. \& Lipman, D.J. (1990) Basic local alignment search tool." J. Mol. Biol. 215: 403-410.

Ardiana D, 2009. Teknik Isolasi DNA genom tanaman papaya dan jeruk denganmenggunakan modifikasi Buffer Ctab.Buletin teknik Pertanian 14(1):1216.

Consortium Barcode of Life (CBOL). (2009). A DNA Barcode for Land Plants. PNAS, 106 (31).

Edgar, RC (2004) MUSCLE: Multiple sequence aligment with high accuracy and high throughout. Nucleic Acid Research 5:1792-1797.

Fazekas, AJ, Burgess KS, Kesanakurti,PR,Graham SW, Newmaster SG, Husband BC,Percy DM,Hajibabaei M, Barret S C H, 2008. Multiple multicolus DNA barcodes from the plastid genome discrimate plant species equally well. Plos one 3: 2802.

Hollingsworth PM, Forrest LL, Spouge JL, Hajibabaei M, Ratnasingham R. 2009. A DNA barcode for land plants. Proc. Natl. Acad. Sci. USA. 106: 12794 - 12797.

Julianti E., Pinaria, A., Lengkong EF, Kolondam BJ. 2015. DNA Barcoding
Tanaman Daluga (Cyrtosperma spp) dari Kepulauan Sangihe berdasarkan Gen matK. Jurnal Bio Logos 5(2): 47-52.

Kearse, M., R. Moir, A. Wilson, S. StonesHavas, M. Cheung, S. Sturrock, S. Buxton, A. Cooper, S. Markowitz, C. Duran, T. Thierer, B. Ashton, P. Meintjes, and A. Drummond (2012) Geneious Basic: An Integrated and Extendable Desktop Software Platform for the Organization and Analysis of Sequence Data. BIOINFORMATICS 28(12), 1647-1649.

Kress WJ, Erickson DL, 2007. A two-locus global DNA barcode for land plants, the coding rbcl gene complements with the no coding trnH-psbA spacer region.Plos One 2(6) Doi:10,1371/0000508.

Newsmaster SG,Ragupathy S (2009). Testing plant barcoding in a sister complex of Pantropical acacia (Mimosaidea,Fabaceae). Molecular Ecology Resources 9:172-182.

Rao, S; M. Taylor, A.Jokhan, 2014. A descriptor list for giant swamp taro (Cyrtosperma merkusii) and its cultivars in the Federated States of Micronesia. TELOPEA. 16:95-117.

Rahayu, DW; Jannah, M. 2019. DNA Barcode Hewan dan Tumbuhan Indonesia.Yayasan Inspirasi Ide Berdaya.

Tallei, T., Kolondam BJ. 2015. DNA Barcoding of Sangihe Nutmeg (Myristica fragrans) using matK Gene. HAYATI Journal of Biosciences 22(1): 41-47.

Taulu, L.P., Layuk, 2014. Dukungan teknologi untuk mempekuat daya saing pangan lokal di Sulawesi Utara. Buku Memperkuat daya saing produk pertanian. IAARD Press. 389-400.

Virgilio M, Jordaens K, Breman F. 2012. Turning DNA barcodes into an alternative tool for identification African fruits, files as a model (poster). Consorsium Barcode of Life (CBOL). 